\title{
Public Diplomacy in the Belt and Road Initiative within the New Media: Theories and Practices
}

\author{
By Li Hongxiu*
}

The Initiative of the Belt and Road Initiative is an international cooperation that the Chinese government put forward to benefit more than 60 countries. This thesis tries to put theories of public diplomacy relating to The Belt and Road Initiative within new media communications, and to resolve how new media public diplomacy pushes communication and exchange between the countries of the Belt and Road Initiative. Through a literature review about the theory of public diplomacy and new media public diplomacy, this article attempts to use the theory of new media public diplomacy and visual graphic expression to construct the model of new media public diplomacy of The Belt and Road Initiative between the governments and the masses and within the masses themselves. Through investigation of new media public diplomacy of The Belt and Road Initiative with theoretical research and practical approach and under the guide of top-level designs from the government, this article will smoothly push new media public diplomacy between Chinese masses and the country masses of The Belt and Road Initiative, and finally realize the goal of interlinking the mass mind. Under new media communication, this article can be used to analyze the current situation of public diplomacy within The Belt and Road Initiative project and be used to practice new media public diplomacy along the countries of The Belt and Road Initiative and estimate its implementation effects in the future.

Keywords: new media public diplomacy, masses, mass mind interlinked, The Belt and Road Initiative.

\section{Introduction}

In 2013, President Xi Jinping put forward The Belt and Road Initiative Initiative, which conformed to the need for regional and global cooperation, and got responses from more than 60 countries and international organizations. In March 2015, the National Development and Reform Commission, the Ministry of Foreign Affairs and the Ministry of Commerce jointly issued The Push to Build a Silk Road Economic Belt and Twenty-first Century Maritime Silk Road Vision and Action (hereinafter referred to as the Vision and Action). It puts forward the ideas of Policy Communication, Infrastructure Cooperation, Trade Cooperation, Financial Cooperation, and People Cooperation as the "Five Cooperations". ${ }^{1}$ In July 2016, The Belt and Road Initiative Media Cooperation Forum was held in Beijing, and 101 countries' media organizations took part in it. President Xi Jinping sent a congratulatory message to the forum (Xinyang, 2016). In May 2017, The Belt and Road Initiative International Cooperation Forum was held in Beijing, China. The leaders of 29 countries attended, and more than 4,000 reporters reported on the forum (Kui \& Jiawei, 2017). Thus, The Belt

\footnotetext{
*Professor, Humanities School of Chongqing Jiaotong University, China.

${ }^{1}$ The concept of "Five Cooperation" was put forward in The Push to Build a Silk Road Economic Belt and Twenty-first Century Maritime Silk Road Vision and Action in March 2015. It is the abbreviation of the five concepts of policy cooperation, facilities cooperation, trade cooperation, financial cooperation and people cooperation. It is explained in detail in the document, and the important cooperative subjects in the Belt and Road Initiative.
} 
and Road Initiative is steadily advancing, and slowly has become a focus of international public opinion and debate. The Belt and Road Initiative People Connected is the base of public opinion, which realizes the multilateral cooperation, and it needs to carry out extensive public diplomacy and international communication, within the heritage and spirit of friendly cooperation in the Silk Road. Therefore, public diplomacy and international communication of The Belt and Road Initiative are not only important contents that promote regional cooperation, but also the main objectives that orient The Belt and Road Initiative.

The Belt and Road Initiative is proposed by the Chinese, but the goal is to promote regional cooperation and common development. Therefore, when thinking of The Belt and Road Initiative, we should have the vision of the world and the international communication field in mind, as well as be willing to jump out of the traditional propaganda mode and get rid of Emphasizing International Discourse and Self Centered nationalism propagation framework. From the present situation, The Belt and Road Initiative cooperation have been placed in the global perspective of new media. China's diplomatic relations with other countries must move from state-centered to citizen-centered public diplomacy (Fan, 2016). The core problem that this paper will solve is how to carry out The Belt and Road Initiative Public Diplomacy in the context of the new media. In order to solve this problem, the following questions need to be solved step-bystep. First, what is the full picture of the theory of Public Diplomacy? What is the new media public diplomacy? At the same time, and according to the actual context of The Belt and Road Initiative, does this theory path have defects that need to be corrected? In the theoretical framework of public diplomacy, what path should The Belt and Road Initiative new media communication follow?

It is necessary to point out that the Public Diplomacy Research of The Belt and Road Initiative, like most other related research, belongs to research of the application type. For applied research, this theoretical analysis is intended not only to provide an analytical path for academic research, but also to provide theoretical guidance and an evaluation basis for practice, with both academic and practical functions. From the perspective of new media, discussions of The Belt and Road Initiative public diplomacy can be used not only for analysis and evaluation of the current situation, but also for the assessment of future public diplomacy planning and its implementation effects. It is a kind of experience research and critical research combination. This is also the research significance of this question.

\section{Decentralization: \\ The Difference between Public Diplomacy and Government Diplomacy}

Public diplomacy was developed on the basis of traditional government diplomacy. As such, its development history is not long, but it is different from government diplomacy in important ways. At present, public diplomacy is attracting more and more attention from scholars, and more and more governments are now paying attention to it. 


\section{The Proposal and Development of the Concept of Public Diplomacy}

It is generally believed that public diplomacy was first put forward by Dean Edmund Gullion in the Fleischer Law and Foreign Affairs College of Tufts University in America in 1965. He said:

"The goal of public diplomacy is that deals with the public attitudes towards government foreign policy and generated influence. It goes beyond the traditional diplomacy, and includes multiple dimensions of international relations, a national government cultivates and guides public opinion to the other countries, the interaction between the interest groups of two countries, foreign affairs report and its effect in policy, communicators communication between diplomatic envoys and foreign correspondents, cross-cultural communication etc." (Danyan, 2017).

This concept is actually an extension and expansion of the traditional government diplomatic concept. In other words, Edmund Gullion's public diplomacy concept contains government diplomacy. It demands that the guidance of public opinion and intercultural communication be carried out under the leadership of the government. Its main content is thus still government diplomacy.

Although Edmund Gullion put forward the concept of public diplomacy, it has not been studied for a long time and has not been popularized in the diplomatic practice of other countries. In 1981, the famous German philosopher Habermas published the Theory of Communicative Action in which he put forward the concept of communicative rationality and made a theoretical analysis of public diplomacy from the perspective of social reality and philosophy. Habermas made a historical exploration of the social contradictions in late capitalist society and deeply thought about communication in the social and public fields. He concluded that communicative action in the public sphere is very important to the life world. Communicative actions use language and nonverbal symbols as tools to understand the public's respective actions, so that they can agree on how to effectively coordinate their behaviors. The behavior of communication yields the synthesis of the subjective world, the objective world and the social world, and thus it is rational behavior. Habermas's theory of communicative action provides a theoretical basis for the practice of public diplomacy and also promotes the development of research regarding public diplomacy.

\section{The Discussion of Public Diplomacy by Scholars}

With the increasing influence of Habermas's theory of communicative action in academic circles all over the world, the research of public diplomacy has attracted the attention of more and more scholars. The connotation of public diplomacy has been further developed and enriched. In 1987, the International Relations Term Dictionary from the United States defined public diplomacy in the following way:

"It is all kinds of activities that the government initiates communication projects, uses means of information dissemination such as radio, understands and influences the other countries public opinion, reduces misconceptions which other countries' 
public generates to America, avoids to cause the complicated relations, improves the United States' image and influence in the foreign public, and increases the national interests of the United states" (Xiaosong \&Yi, 2003).

This concept attaches great importance to the role of the media in public diplomacy, as well as to the process of communication with the foreign public. With the rise of informal and small groups in transnational civil organizations, Anthony G. McGrew even put forward the concept of citizen diplomacy. Creating transnational citizens is the goal, which should be achieved by promoting exchanges and cooperation between citizens in order to construct a basic transnational civil society (McGrew, 2003).

Due to the increasingly prominent position of citizen diplomacy in public diplomacy, many scholars have made more extensive studies of the objects and forms of public diplomacy. Japanese scholars Kaneko Masafumi and Kitano believe that in order to deepen their understanding of the object, "Public Diplomacy is not only the person and organization of the target nation, but also the individual and organization of the third nation" (Masafumi \& Kitano, 2010, p. 9). For example and regarding Japan's relations with China, China is the destination where they hope to carry out public diplomacy, but this is not limited to Chinese individuals and organizations; indeed, attention is also paid to American individuals and organizations, because the United States is one of Japan's allies. Russian scholar Sub F. Lukin thinks that the main players of public diplomacy are non-governmental organizations, on the one hand because they can "promote national policy" and on the other hand because their goals are "realized through direct contact with other civil society NGOs" (Lukin, 2013). The government thus does not play a direct role in public diplomacy, and direct action is instead through the direct communication between non-governmental organizations and individual citizens of both countries, in order to carry out mutual exchanges.

\section{The Relationship between Public Diplomacy and Government Diplomacy}

Some scholars have divided public diplomacy into four types: cooperative public diplomacy, competitive public diplomacy, normal public diplomacy and crisis public diplomacy (Xiaosong \& Zichu, 2016). These four types are the summing up of an in-depth study of public diplomacy. The former State Council Information Office Director Zhao Qizheng has studied Public Diplomacy for years. He also believes that the subject of public diplomacy is relevant to "more than the government, such as non-governmental organizations, universities, research institutions, media, religious organizations at home and abroad as well as influential people". They can often play a role in international relations that the government cannot replace (Qing'an \& Xianzhang, 2009). Zhao Qizheng pointed out the difference between public diplomacy and traditional government diplomacy. Although there is a connection between public diplomacy and government diplomacy, it is not an inclusive relationship. Rather, it is a different relationship. Government diplomacy is the exchange between two country governments. Public diplomacy is the exchange between two countries nongovernmental organizations. 
Figure 1. Complementary between Public Diplomacy and Government Diplomacy

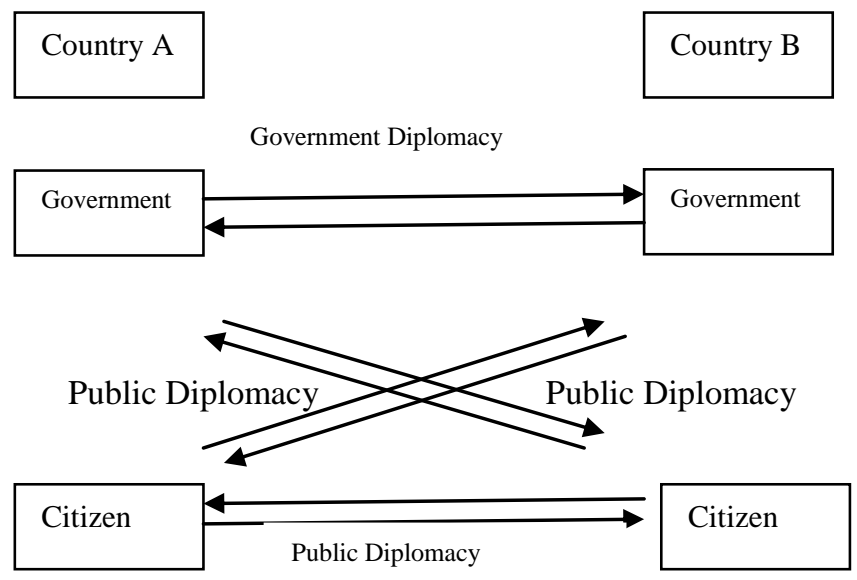

It can be seen from Figure 1 that traditional government diplomacy involved a fixed, relatively narrow range, while the object of public diplomacy is extensive with a very broad space, especially regarding public diplomacy between citizens, and between the citizen and the government, which plays an increasingly important role. Public diplomacy thus gradually goes from the edge to the center. Some Chinese scholars invariably pointed out that China's diplomacy should be transformed from "state-centered" to "citizen-centered", and the individual people should be built up in a diplomatic arrangement that is "people-oriented and [offers] diplomacy for the people" (Fan, 2016). With the acceleration of globalization, the opportunities for transnational communication between our public, enterprises and NGOs are increasing. The main body of diplomacy is no longer confined to government agencies; the diplomatic activities of ordinary citizens are becoming important new subjects.

Joseph Nye who put forward the idea of soft power even stressed that it is close relationship between soft power and national image. "American soft power is declining and the of Chinese soft power is rising" (Wang, 2008). Public diplomacy thus plays a crucial role in shaping the national image through the active participation of the public, society and enterprises, and improves the national image and international influence. The relationship is very close between public diplomacy and national image. On the one hand, public diplomacy closes the distance between the domestic public and the foreign public, and thus the influence of foreign public awareness of a country's national image can be effectively spread. On the other hand, a good image of the country is the foundation of public diplomacy, and it can enhance mutual understanding to further promote exchange and cooperation between countries.

To sum up, we may be able to put forward a relatively ideal model of public diplomacy. Public diplomacy is a new diplomatic pattern that is related with traditional government diplomacy, but is still independent of it. Its behavioral subjects are non-governmental organizations and individuals, while its audience is the foreign public, and its communication channels are cultural exchange and media. The main goal is to promote mutual understanding between both the government and the public and the domestic public and the foreign public, thus 
affecting the cognitive attitudes of the foreign public. It is important to note that although this model emphasizes the importance of public diplomacy, it cannot replace government diplomacy. Therefore, in consideration of The Belt and Road Initiative public diplomacy, the status of the national government and the form of cooperation still need to undertake careful consideration of the issues.

\section{Channel Change: from Public Diplomacy to New Media Public Diplomacy}

Public diplomacy is always developing and changing, especially regarding the channels for public diplomacy, which are becoming more diversified with further development. Media diplomacy is an important part of public diplomacy. With the development of media technology, traditional media is giving way to new media. New media public diplomacy has therefore become one of the main channels of public diplomacy.

\section{Media Diplomacy in Public Diplomacy}

Many scholars have realized that the media plays an important role in public diplomacy. As the role of public diplomacy is to publicize the desired image of the country, it is necessary to use the wide media to achieve its purpose (Fei, 2015). Within this, there is also a special term for Media Diplomacy in English. The media in the world are all expressing their national image and their foreign policy. There is also close interaction between different countries through various methods, such as illustration, communication, commentary and debate. This versatility is the power of media diplomacy. The public is the main body of public diplomacy, so the role played by the media is very critical. Zhao Kejin believes that public diplomacy uses "two-way communication with foreign public through communication, public relations, media and other means" to better shape the national image and achieve the purpose of "improving national popularity, reputation and recognition" (Kejin, 2007).

\section{The Concept and Connotation of the New Media}

The first scholar who put forward the concept of new media was Marshall McLuhan, a Canadian communications scientist. On March 3, 1959, McLuhan published an academic speech in Chicago entitled The Revolutionary Influence of the Electronic Revolution: the New Media. "From a long-term point of view, the media is a message," Mcluhan said. He continued:

\footnotetext{
"So when the community develops a new medium based on collective action, such as printing, telegraph, photo and radio, it gains the right to express new information. Today, the king of printing is over, and the oligarchy of the new media usurped the Monarchy of 500 years. In an oligarchy, every new medium has the same strength as printing, transmitting the same message" (Mcluhan, 1967, 2006, p. 3).
} 
The American NTSC (National Television Standards Committee) standard TV inventor P. Goldmark also released a report on the development of an electronic video product plan, including the use of the new media concept (An'xiang, 1999, p. 72). However, Mcluhan and Goldmark use slightly different conceptions of new media from what is seen in today's new media. The new media of which they speak is different from printed media newspapers, and refers to telegraph, telephone, radio, movies, television and other electronic media. Yet, today's new media refers to the emergence of certain media platforms after the birth of digital technology and the Internet.

At present, the definition of new media, as well as its emergence and various aspects, is differently conceived from different members of the academic community. Some scholars believe that the spread of new media occurred in the late 1980s with the Gulf War and presidential campaign, making TV and Internet tools of a political campaign. The media turned from elite control to public dominance (Davis \& Owen, 1998). On the other hand, some scholars believe that the new media is a mobile, interactive, free media. Although the new media is highly dependent on the computer, it is not only digital media that to a large extent is a new interactive media (Kyong Chun, 2006, p. 1). Some other scholars believe that new media refers to the form of information dissemination based on the Internet and mobile terminals, for example computers, mobile phones and other media (Fei, 2015). In sum, new media is a general term for all kinds of new media forms based on digital technologies and the Internet, such as computer networks, computers, mobile phones, digital TV, social networking platforms, and so on. Compared with traditional media, the main features of new media age are digital communication, network communication and global communication (Lu \& Fangzhou, 2013). Ordinary people can interact easily with new media, and thus encourage democratization of the creation, publication, dissemination and consumption of media.

\section{New Media and New Media Public Diplomacy}

The integration of new media and public diplomacy has spawned new media public diplomacy. New media public diplomacy refers to activities such as external communication, external publicity and diplomatic participation within the information age, which is based on Internet technology and network platform (Meng, 2009). Actually, the technical foundation of new media public diplomacy is the Web 2.0 network, and its communication form is digital communication with direction towards the foreign public. Therefore, some scholars called it Public Diplomacy 2.0 or web-based public diplomacy (Gilboa, 2008; Seib, 2011; Shirky, 2011). Some scholars directly call the new media public diplomacy Web2.0 Diplomacy (Xingqing, 2014), in order to better distinguish from the traditional media's public diplomacy. With the support of Web2.0 technology, social platforms such as WeChat, Micro-blog, Wiki, Facebook, Twitter and YouTube have become important channels for public information exchange in various countries. Song Lilei and Bian Qing summed up the four characteristics of the new media public diplomacy: the orientation of the target group is more distinct; the communication mode is immediate and bidirectional; the content of 
information communication emphasizes originality and relevance; and the communication goal is transformed from notification to influence (Lilei \& Qing, 2014). These characteristics explain why new media public diplomacy is welcomed by the public in all countries. In this way, diplomatic behavior has gone from the official sector to the private sector and from passive to active.

Although new media public diplomacy has many ideas and positive characteristics in theory, it also faces many difficulties in actual practice. Matthew Wallin, a public diplomacy researcher, pointed out that using social media to achieve the purpose of government public diplomacy may be more difficult than many practitioners predict (Wallin, 2012, 2013). Cyberspace, as a virtual open space, provides convenience for public diplomacy, but also increases the vulnerability and uncertainty of public diplomacy. It is difficult for the state to control the public diplomacy of the new media. Comments about the image of the country are easily spread around the world through new media technology. Scholars have also pointed out that the public in new media public diplomacy and foreign governments are sometimes inconsistent. Cyberspace is a platform to express the political views for netizens, and it can also be regarded as a way to vent their emotions. For instance, extreme nationalism on the Internet is mainly caused by intense emotions. Those extreme and irrational remarks are admired, while rational mild comments are belittled. Most of the netizens between them are also becoming more extreme under the influence of extreme speech and powerful forces. As a result, the Internet has become the world of extreme nationalism (Mingge, 2013). In such a complex virtual environment, the advantage of new media public diplomacy is obvious. However, the complexity of network society will inevitably bring about the problems and puzzles of new media public diplomacy, which cannot be avoided or ignored.

\section{The Role of the People: Theoretical Thinking of New Media Public Diplomacy in the Belt and Road Initiative}

The countries involved in the Belt and Road Initiative are numerous and have vast linguistic and cultural differences between them. It is not convenient for them to share consistent contact and exchange between their peoples. Therefore, is it possible for public diplomacy to be implemented in The Belt and Road Initiative and its relevant countries? The answer is yes. However, the implementation of traditional public diplomacy is not convenient, and the effect is rather poor. The new media public diplomacy is more convenient and feasible, and can thus achieve the real effect of connecting people.

\section{The Possibility of the Implementation of New Media Public Diplomacy in The Belt and Road Initiative}

The Belt and Road Initiative includes more than 60 countries and 4.4 billion people from areas such as Central Asia, West Asia, South Asia, Southeast Asia, and Africa, as well as Central and Eastern Europe. Exchanges between these countries have become increasingly frequent, and cooperation will continue to 
develop. The Vision and action plan emphasizes: "Extensive cultural exchanges, academic exchanges, talent exchanges and cooperation, media cooperation, youth and women's contacts, volunteer services, etc., so as to lay a solid foundation for deepening bilateral and multilateral cooperation". Thus, the media cooperation that carries out public diplomacy in The Belt and Road Initiative countries are very important. NPC Standing Committee Vice Chairman Wang Chen pointed out during the 2016 Belt and Road Initiative Media Cooperation Forum that the media should be the Traveler, the Singer and the Messenger ${ }^{2}$ in The Belt and Road Initiative countries (Chen, 2016) Some scholars concluded that media public diplomacy has three potential purposes in the Belt and Road Initiative: to attract foreign media attention, to put out active propaganda, and to encourage media cooperation and communication between China and foreign countries (Ruihong, 2016). No matter what kind of media communication is used, public diplomacy is conducive to the people in The Belt and Road Initiative countries better understanding each other's cultures, strengthening their cultural identities, deepening mutual trust, further promoting economic development and cooperation, and building strategic partnerships.

The emergence of new media has greatly expanded public diplomacy communication channels for different countries between multiple governments, the governments and their respective publics, and the multiple publics. This communication interaction provides multi-level platforms, resulting in taking the functions of public diplomacy from single to multiple. Similarly, the new media public diplomacy is feasible in the Belt and Road Initiative countries. First of all, the Belt and Road Initiative countries pay attention to Internet construction, and their new media technology is very mature. For example, the Qatar News Agency has set up the world's first social news website, Qatar Maydan. Russia has a variety of new media TV websites, such as CTC TV network, THT TV network and so on. Serbia also has a large number of Internet media. Secondly, the countries along the Belt and Road Initiative use new media to contact more and more people, especially young people who are gradually abandoning traditional paper books and newspapers. Again, the new media carrier has a high popularization degree in the Belt and Road Initiative countries. Although economic development is not balanced between these countries, mobile phone users showcase a trend of rapid growth in different technological sectors across nearly all countries. Mobile phone use is popular in people of the Belt and Road Initiative countries. The new media thus not only provides abundant information for people living along The Belt and Road Initiative, but also are more advanced in the efficient dissemination of information. Therefore, new media public diplomacy is richer and more effective along the Belt and Road Initiative. Some scholars have pointed out that new media public

\footnotetext{
${ }^{2}$ Wang Chen said, the media should travel in The Belt and Road Initiative countries because it should communicate the spirit of the Silk Road and spread positive energy. The media should be a Singer in The Belt and Road Initiative countries because it should interpret the spirit of the Silk Road and talk about the story of the Silk Road. The media should be a Messenger in The Belt and Road Initiative countries because it should strengthen cultural exchanges and enhance mutual understanding and mutual trust between The Belt and Road Initiative countries.
} 
diplomacy, which is carried out in the Belt and Road Initiative countries, should adhere to the following principles: mutual respect, multiculturalism, and new technology communication.

\begin{abstract}
"In the new media environment, the culture transmission mode of The Belt and Road Initiative should stick to the mutual intersection of communication mode, and the principle of coexistence of multiple patterns with choosing the adsorption of propagation model and the advantages of the diffusion pattern and so on" (Yu, 2015).
\end{abstract}

Therefore, in the new media public diplomacy, those participating in the Belt and Road Initiative should insist on the use of new media and new technology to lead public diplomacy. In this way, they can push forward public diplomacy of the Belt and Road Initiative and lead towards faster development.

\title{
Partnership between New Media Public Diplomacy and Government Diplomacy in the Belt and Road Initiative
}

With the development of new media and the implementation of The Belt and Road Initiative, scholars began to study relationship between new media public diplomacy and The Belt and Road Initiative countries. In Russia, Kazakhstan, Kyrgyzstan, Tajikistan, Ukraine and other central and Eastern European countries, the most widely used social media is Vkontakte network, with 239 million registered users. This social media often reports China. This news is relatively fair, neutral about Chinese image. The positive news is more than the negative news (Yun, Miaomiao, \& Yi, 2017). At the same time, China Xinhua News Agency also increased the coverage of new media on The Belt and Road Initiative the countries. It attracts the audience by music, WeChat, micro-blog, H5, and other multimedia, and gives full play to the role of new media public diplomacy (Shuping, 2017). Of course, some scholars have studied the negative impact of new media on public diplomacy. Since 2003, the Color Revolution has erupted in Ukraine, Georgia and other countries, because the American value concept influences mass ideas by the new media communication. These ideas stem from the new media dissemination by the West countries. They have caused serious damage to the stability of the state power (Fei, 2015).

The Belt and Road Initiative countries should learn from the experience of the American government in dealing with the relationship between government diplomacy and the new media public diplomacy. In recent presidential elections, presidential candidates have attached great importance to role of new media. When Obama was elected, he made full use of network tools, such as video, podcasts, blogs and web ads and so on, so as to maximize the support of Internet users. After Obama was elected president, 25 government departments set up Youtube channels. Library of Congress has uploaded thousands of historical photos on the Flickr. 30 more federal agencies, including the White House, join the Facebook. Obama pushed the US public diplomacy policy into the era of "public diplomacy 2.0" (Zhongbin, 2011). Therefore, some scholars have suggested that the full use of visits between the leaders of countries, and strengthen the political trust between China and The Belt and Road Initiative 
countries, increase media propaganda. At the same time, we should strengthen China government to construct external websites by the official network media (Yun, et al., 2017). Based on the studies of scholars, the author develops a model of cooperation between government diplomacy and new media public diplomacy in The Belt and Road Initiative countries.

Figure 2. New Media Public Diplomacy Modes of the Belt and Road Initiative Countries

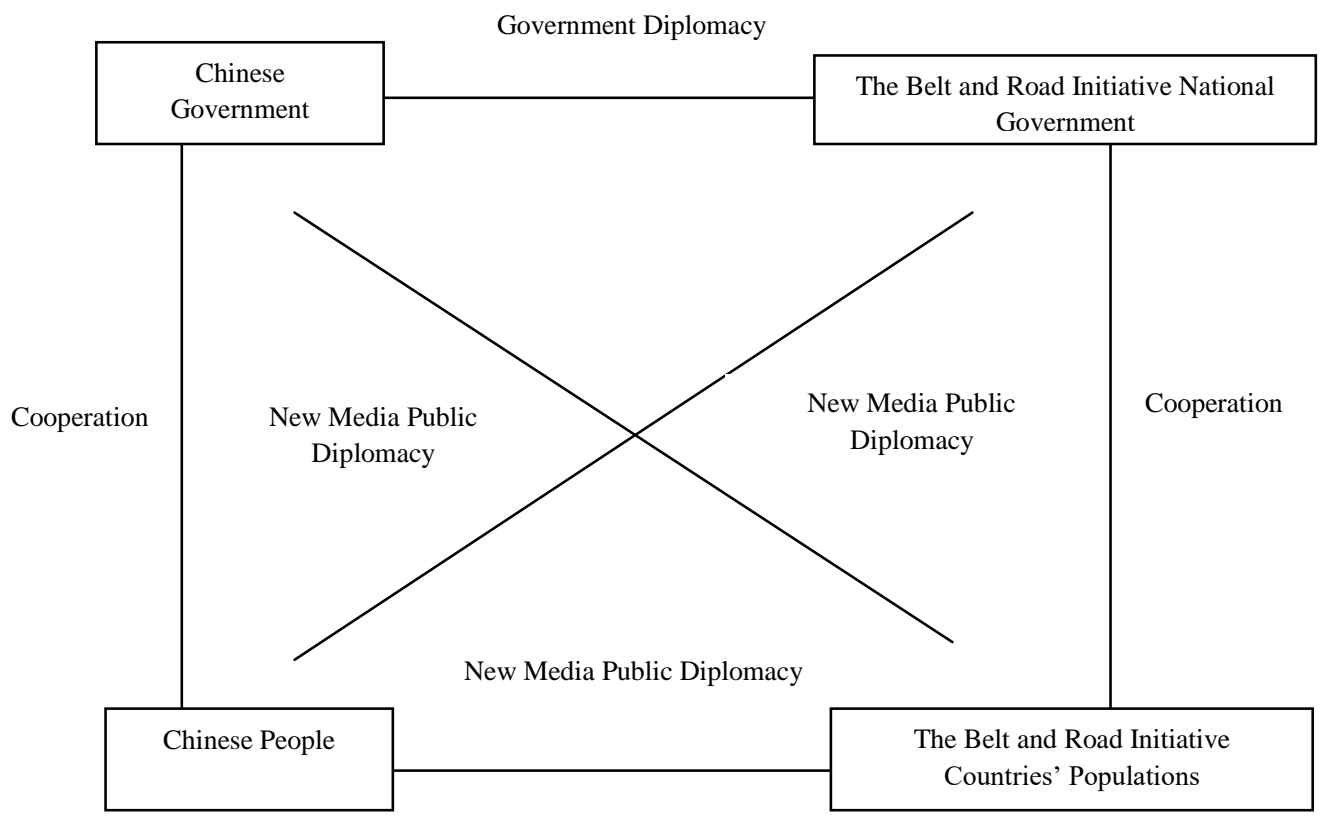

From the public diplomacy mode of new media within countries along The Belt and Road Initiative, we can see that if there is no new media, communication channels are limited between the Chinese government and the rest of the involved national governments (Figure 2). In this context, communication mainly stays at the governmental and diplomatic level. Communication between the various national populations is difficult to achieve. After the emergence of new media, however, public diplomacy becomes rich and diverse, not only between the Chinese people and the people of other nations along the Belt and Road Initiative, but also between the Chinese government and the other populations, as well as the Chinese people and the other national governments in order to carry out public diplomacy. Considering the essence and purpose of public diplomacy is to project influence, the effect of a country's public diplomacy depends largely on whether the information sent by that country can be accepted and correctly interpreted by the audiences, and then eventually transformed into a positive impact. That is to say, if new media public diplomacy can be carried out effectively in the Belt and Road Initiative countries, the Chinese people are key factors.

If they have good relations of cooperation between the Chinese people and their government, new media public diplomacy can carry out positive effects between Chinese people and the people of the other nations. Even if there is contradictory information or confrontations between the Belt and Road Initiative 
national people and the Chinese government, these can be resolved through communication between the Chinese people and The Belt and Road Initiative national people. On the contrary, if the dissemination of information in China's public is interfering with or antagonistic to the official information from China's government, then new media public diplomacy will cause negative effects between the Chinese people and The Belt and Road Initiative national people. This could form a confrontation between The Belt and Road Initiative national people and the Chinese government. The people living along the Belt and Road Initiative will put pressure on The Belt and Road Initiative national government and attack government diplomacy between the Chinese government and their respective national governments. Therefore, when new media public diplomacy of The Belt and Road Initiative is carried out, the Chinese government must attach importance to the role of the public, and let the Chinese people exert influence through the guiding role of public opinion in the new media in order to reduce potential negative impacts on public opinion of other national peoples, and thus allow the initiative to be implemented smoothly.

\section{People Connected: The Practice of New Media Public Diplomacy in the Belt and Road Initiative}

Based on the above theoretical and practical discussion, new media is clearly the basic concept of the public diplomacy framework as applied to The Belt and Road Initiative.

\section{The Top-Level Design of New Media Public Diplomacy in the Belt and Road Initiative}

To implement The Belt and Road Initiative through new media public diplomacy, the Chinese government and the governments of other countries along the Belt and Road Initiative must make use of good top-level design. Interactions between the various diplomatic leaderships belong to the realm of government diplomacy, and government diplomacy cannot replace public diplomacy or vice versa. However, public diplomacy must be carried out in the guidance of governments and must comply with the overall interests of the countries. There is no communication between organizations outside the government and the Chinese people or other national populations, and there is no more new media from outside the state system. The new media public diplomacy between the people of the countries along the Belt and Road Initiative must be guided by the governments, and there are plans to gradually achieve cooperation and exchange for free communication purposes.

As previously stated, the author divides new media public diplomacy of The Belt and Road Initiative into four types: cooperative new media public diplomacy, competitive new media public diplomacy, normal new media public diplomacy and crisis new media public diplomacy. Each of these four types, along with a top-level design value, could have a guiding role in the new media 
public diplomacy of The Belt and Road Initiative. In cooperative new media public diplomacy, The Belt and Road Initiative countries should consider the feasibility of the new media public diplomacy according to different linguistic and cultural backgrounds, and make different new media public diplomacy plans. In competitive new media public diplomacy, the new media public diplomacy of The Belt and Road Initiative must cope with challenges from network nationalism, network extremism and cyber terrorism. So The Belt and Road Initiative country governments should strengthen cooperation in new media public diplomacy. In normal new media public diplomacy, differentiated communication strategies of new media should be made between The Belt and Road Initiative national peoples. In crisis new media public diplomacy, the Chinese people should strive to improve their position as a guiding force in the international public opinion of The Belt and Road Initiative, by promoting the new media public relations ability (Figure 3 ).

Figure 3. Implementation Path of New Media Public Diplomacy in The Belt and Road Initiative

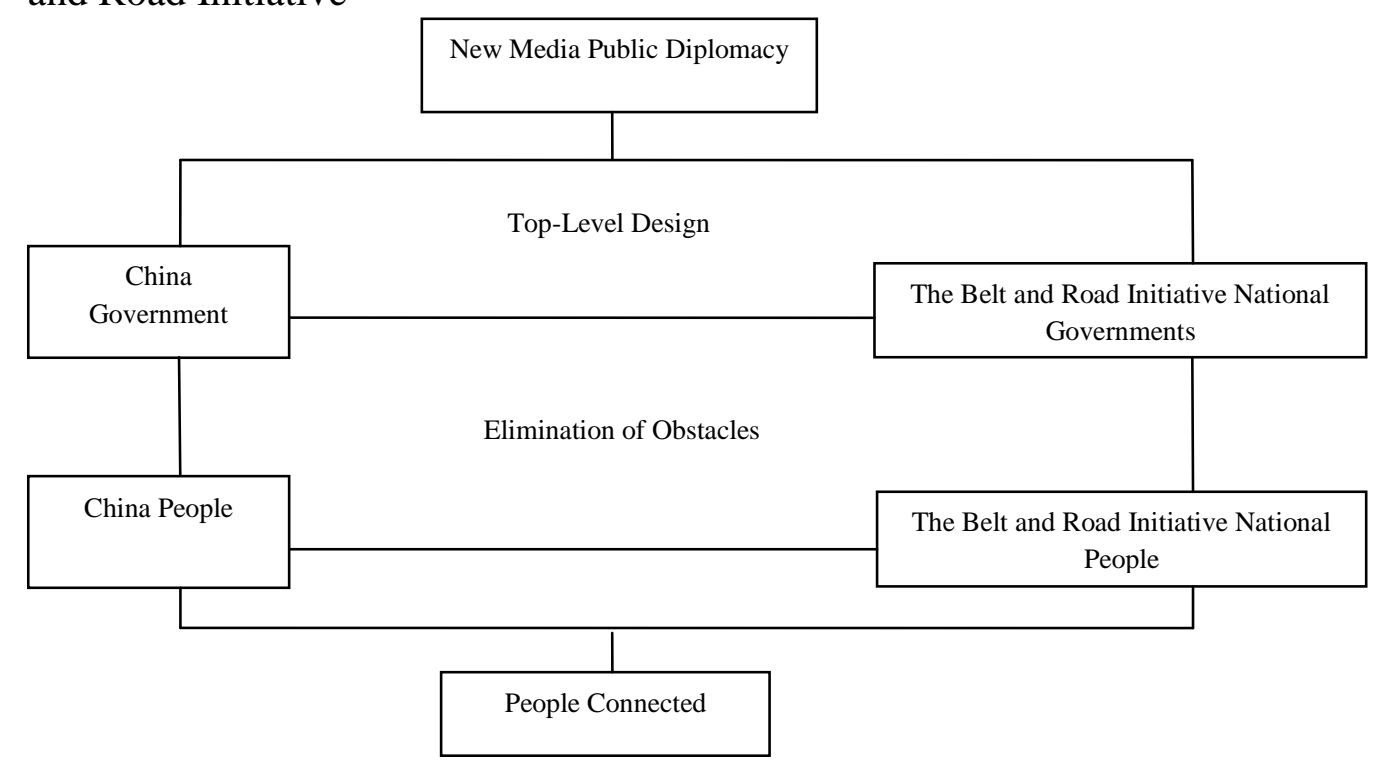

\section{Implementation Case of New Media Public Diplomacy in the Belt and Road Initiative}

At present, the Chinese government has played an important role in the top level design of the new media public diplomacy. Xinhua Net, People Net, China Net and other web portals have opened in English, French and Russian language versions, and multi-language and multi-angle reports of the news about China and The Belt and Road Initiative are being publicized to other countries. At the same time, the Xinhua News Agency has an official unified account, "New China," on overseas social media platforms, which pushes news related to China by text, picture and video. However, The Belt and Road Initiative national economic development level is not balanced. The Belt mainly exists in 
Kazakhstan, Kyrgyzstan, Uzbekistan, Tajikistan and other Central Asian countries, and these countries' economic levels are relatively low. Their social systems and media systems are influenced by Russia, and traditional media and new media are both underdeveloped. Governments play an important and powerful role in the new media public diplomacy. Under the top-level design of the state, the Chinese government and local governments should help The Belt countries to strengthen the construction of new media technology and lay the technological foundation for new media public diplomacy by playing a leading role in new media cooperation.

The Road countries are mainly in Southeast Asia, South Asia and the Middle East Gulf countries. Compared to the countries along the Belt, their economic development is better, and their media level is higher with a relatively developed Internet system. Therefore, new media public diplomacy is easier to achieve in these countries. The top-level design of new media cooperation is thus more convenient between the Chinese government and the Belt and Road Initiative national governments. In this case, utilizing the local government is more practical than the overall deployment of a national strategy. China's Xinhua News Agency and Qatar satellite TV set up a cooperative relationship for the sharing of news resources in the 1990s. In 2008, China and ASEAN signed the News Media Cooperation Memorandum of Understanding, planning to facilitate news cooperation between the two sides and to make specific arrangements in the development of human resources, media exchanges and joint programs, such as a China-ASEAN media network and other aspects of cooperation. They have thus laid a solid foundation for new media public diplomacy between China and ASEAN (Jiansi, 2009). In Singapore, the Philippines, Malaysia, Thailand and Indonesia, Mandarin channels, columns and programs have been set up. Guangxi TV station has been completed and the Southeast Asia Multimedia Communication Center has been set up. Here, they opened a China TV Play column, and through the cooperation with Vietnam digital TV, Guangxi satellite TV can be broadcasted in Vietnam. The new media of Guangxi People Broadcasting Station "Beibu Gulf online" is a network platform working in 4 languages: English, Cantonese, Thai and Putonghua, and its audience is mainly composed of ASEAN people.

\section{The Government Role in New Media Public Diplomacy from The Belt and Road Initiative}

The main object of new media public diplomacy is to engage with the people of the world. In order for the Belt and Road Initiative countries to achieve new media public diplomacy, it is necessary to eliminate the barriers between the Chinese people and the other national populations involved. To eliminate technical barriers, new media communication and language obstacles, and cross-cultural communication barriers, they should promote a notion of "Many to Many" exchanges and cooperation. In the double transformation of globalization and media on the occasion, the governments should make full use of new media to provide more convenient conditions for people of different countries to 
communicate. In accordance with the principle of mutual respect, cooperation and sharing common ground, they should set up a new mechanism of The Belt and Road Initiative new media cooperation as soon as possible, and construct The Belt and Road Initiative new media integration platform, thereby eliminating barriers to communication between people around the world. In this way, the circle of people positively connected to the Belt and Road Initiative becomes bigger.

Foreign minister Wang Yi used the idea of a Circle of Friends to describe the "influence of The Belt and Road Initiative". "The Circle of Friends in China is getting bigger and bigger; our good friends and good partners are more and more " (Mengzhe \& Shaohua, 2015). The phrase "Circle of Friends" highlights the powerful force and practical effect of new media public diplomacy. Through new media public diplomacy in various forms, Chinese people and the national groups of The Belt and Road Initiative gradually eliminate obstacles between themselves, and finally realize the goal of connecting people in the Circle of Friends. A network president and editor-in-chief from India has said that the new media exchanges and cooperation on The Belt and Road Initiative are a form of "soft infrastructure" to achieve "people connected". This is an essential premise that constructs the Belt and Road Initiative. Inter-media communication and cooperation is an important aspect of cultural exchange, and it will help to promote the overall construction of The Belt and Road Initiative (Jia \& Jiayu, 2016).

\section{Conclusion: Smoothly Promote New Media Public Diplomacy in the Belt and Road Initiative}

New media public diplomacy is an objective requirement in the new era. New media public diplomacy, which is carried out in The Belt and Road Initiative countries, will be a grand strategy throughout Asia and Europe and will benefit the Circle of Friends with billions of people. However, it is not easy to promote smoothly The Belt and Road Initiative new media public diplomacy. Jiang Yimin pointed out:

"The popularization of new media objectively changed the way of information flow between countries, which led to the diversification and complexity of interaction channels among countries, which increased the uncertainty of public diplomacy. It is more important that the new media means expand the interaction channels between countries, promote the interaction between different societies. Therefore, the government diplomacy is affected, and the importance of the inward dimension of public diplomacy is highlighted" (Yimin, 2013).

In The Belt and Road Initiative countries, because of the diversity of social culture and folk customs, speech and thought mix together. As such, new media public diplomacy will inspire positive public opinions and negative public opinions at the same time. Therefore, the Belt and Road Initiative national governments will increase the level of difficulty experienced when trying to orchestrate effective management of new media public diplomacy. 
In the new media era, we cannot cut off from the internet's free exchange between the public in The Belt and Road Initiative countries because of the possible negative impact of information, and cannot also be completely laissez faire to Internet. These two aspects are not conducive to effective implementation of new media public diplomacy. New media public diplomacy is an integrated whole. First of all, The Belt and Road Initiative countries must adhere to the principle of mutual respect when they carry out the new media public diplomacy. Regardless of the size of the country, regardless of population, they should be dedicated to equal exchange, common development. Secondly, government diplomacy in The Belt and Road Initiative countries should play a leading role in the new media public diplomacy. Governments should set up a bridge of new media freedom and communication between the people of The Belt and Road Initiative countries. This will provide convenience for people all around the world of new media communication. However, it will also provide good supervision and guidance to the information communication of new media and make emergency response mechanisms to fight the spread of negative information. Thirdly, The Belt and Road Initiative countries should build strong official platforms regarding new media, strengthen direct communication with people around the world. Governments should establish official accounts on some important social media, such as Youtube, Twitter, Facebook, and Yelp, and make timely updates and maintenance to attract users' attention and interaction. People becoming connected is the ultimate purpose of communication between The Belt and Road Initiative countries, so the new media public diplomacy is the best channel. If the national governments create good top-level design, new media public diplomacy will be pushed smoothly to a new height.

\section{Acknowledgments}

I am grateful to the anonymous reviewers for their critical feedback.

\section{References}

An'xiang, M. (1999). Information Super Highway and Mass Communication. Beijing: Huaxia Press.

Chen, W. (2016). Hand in Hand construction of "The Belt and Road Initiative" community of destiny: Speech In the Belt and Road Initiative Initiative Media Cooperation Forum in 2016. Chinese people's Congress 16, 6-8.

Danyan, W. (2017). Strategy Communication and Public Diplomacy Practice in New Media Times. Youth Journalist 8, 6-7.

Davis, R., Owen, D. (1998). New Media and American Politics. Oxford :Oxford University Press.

Fan, Y. (2016). China Diplomacy Transition: From Nation Centrality to Citizen Centrality. Public Diplomacy Quarterly, 2, 94-98. 
Fei, L. (2015). On the New Media and Fusion Development of Public Diplomacy. China Newspaper Industry, 22, 15-16.

Gilboa, E. (2008). Searching for a Theory Public Diplomacy. The Annals of the American Academy of Political and Social Science, 616(1), 55-77.

Jia, Y., Jiayu, Z. (2016). Propagation Force in foreign media reports about "The Belt and Road Initiative" from the Perspective of New Media. New Media Research, 7, 79-80.

Jiansi, L. (2009). Gradually Entering Blissful Circumstances' Cooperation of News Media Between Guangxi and ASEAN Countries. International Communications, 9, 47-48.

Kejin, Z. (2007). Theory and Practice of Public Diplomacy. Shanghai: Shanghai Lexicographical Publishing House.

Kyong Chun, W. H. (2006). "Did Somebody Say New Media". In W. H. Kyong Chun and T. Keen (Eds.), New Media, Old Media: A History and Theory Reader. New York: Routledge.

Kui, Z., Jiawei, C. (2017). The analysis of The Belt and Road Initiative Summit International media reports International Media Reporting. News and Writing, 6, 34-37.

Lilei, S., Qing, B. (2014). Characteristics and Practice of Public Diplomacy in New Media Times: Base on Case Analysis of Official micro-blog in European Department of the Ministry of Foreign Affairs. European Studies, 4, 112-129.

Lu, W., Fangzhou, D. (2013). On the Transition of Communication Study in New Media Times. Journal of Zhejiang University (Humanities and Social Sciences), 4, 93-103.

Lukin, S. V. (2013). Public Diplomacy: Nation Propaganda or Citizen Initiative. Public Diplomacy Quarterly, 3, 115-121.

Masafumi, K., Kitano. (2010). Public Diplomacy: Diplomacy Strategy of Public Opinion Times. Beijing: Foreign Language Teaching and Research Press.

McGrew, T. (2003). Move Towards Real Global Administer.(Trans.). Beijing: Social Sciences Academic Press.

Mcluhan, M. (2006). Mcluhan Talks Like This. Beijing: Renmin University of China Press.

Meng, J. (2009). New Media Diplomacy: Theory, Strategy and Cases. International Communications, 10, 49-50.

Mengzhe, S., Shaohua L. (2015). "The Belt and Road Initiative" Circle of Friends. People's Daily (Overseas Edition). Retrieved from https://bit.ly/2su6N9t.

Mingge, W. (2013). Risk Analysis of Cyber citizen diplomacy. Contemporary Communications, 5, 56-58.

Qing'an, Z., Xianzhang, H. (2009). Model Reformation of China Public Diplomacy. China Social Sciences Journal, 7(2).

Ruihong, F. (2016). The Interactive Development Analysis of "The Belt and Road Initiative" and Public Diplomacy in Southeast Asia. Guangxi Social Sciences, 9, 44-49.

Seib, P. (2011). Transnational Journalism, Public Diplomacy, and Virtual States. Journalism Studies, 11(5), 734-744.

Shirky, C. (2011). The Political Power of Social Media. Foreign Affairs, 90(1), 28-41.

Shuping, M. (2017). The Belt and Road Initiative Reported from New Media Center of Xinhua News Agency: How to Make Flow over Hundreds of Millions Products Three Dimensions of New Media Resources Integration. Chinese Journalist, 7, 105-106. 
Wallin, M. (2013). The Challenges of the Internet and Social Media in Public Diplomacy. American Security Project. February. Retrieved from https://bit.ly/2xxD5WM.

Wallin, M. (2012). The New Public Diplomacy Imperative: America's Vital Need to Communicate Strategically. American Security Project. August. Retrieved from https://bit.ly/2LOsvh9.

Wang, Y. (2008). Public Diplomacy and the Rise of Chinese Soft Power. The Annals of the American Academy of Political and Social Science, 616(1), 257-273.

Xiaosong, T., Zichu, Z. (2016). China to the "The Belt and Road Initiative" along the Country's Public Diplomacy. Teaching and Research, 6, 50-58.

Xiaosong, T., Yi, W. (2003). Rising of Public Diplomacy Study in America and Selfexamination to American Foreign Policy. World Economy and Politics, 4, $22-27$

Xingqing, P. (2014). Brief Analyzing New Media Public Diplomacy in Obama Government. Pure(Early and Mid), 15, 24-25.

Xinyang, Z. (2016). Important Meanings of Media Cooperation in The Belt and Road Initiative. Distinguished Guests Opinions Extract and Compilation at The Belt and Road Initiative Media Cooperation Forum in 2016. Nation Administer, 2, 33-36.

Yimin, J. (2013). New Media and American Government's Public Diplomacy in the Middle East: A Case Study of the Controversy over Mohamed's Real Life. Public Diplomacy Quarterly, 1, 88-95.

$\mathrm{Yu}$, L. (2015). Study on the mode of The Belt and Road Initiative along Cultural Communication under the New Media Environment. News Research, 7, 23-25.

Yun, L., Miaomiao, Z., Yi, T. (2017). China Image Analysis Within Social Media in The Belt and Road Initiative countries - Based on Chinese report from the social network VKONTAKTE. Journal of Xinjiang Normal University (Philosophy and Social Science), 5, 128-136.

Zhongbin, L. (2011). New Media and Public Diplomacy of Obama Government. American Studies, 1, 110-121. 